\title{
PRÁVNÍ REŽIM PŘÍRODNÍCH ZDROJŮ NA NEBESKÝCH TĚLESECH ${ }^{1}$
}

\author{
ŠIMON PEPŘÍK
}

\begin{abstract}
The Legal Regime of Natural Resources of Celestial Bodies
The aim of this article is to describe the legal regime of the natural resources of celestial bodies. In recent months and years, there has been an increase in debates regarding mining on the moon and asteroids. This article is dedicated to the analysis of the legal regime of such activities. In particular, whether such activities are possible from the point of view of international law, how they are regulated and what are the potential future developments in this area.

The article offers an analysis and comparison of the legal regime governing the natural resources of celestial bodies based on the Outer Space Treaty and the Moon Agreement, respectively. The Moon Agreement is given special attention despite its limited international significance, and arguments are presented in favour of its possible recognition by more states in the future. In both cases, arguments are presented that the non-appropriation principle regarding the outer space and celestial bodies, as expressed in both international treaties, does not apply to the natural resources.
\end{abstract}

Keywords: legal regime; natural resources; celestial bodies; outer space

Kličová slova: právní režim; prrírodní zdroje; nebeská tělesa; kosmický prostor

DOI: $10.14712 / 23366478.2021 .30$

\section{1. ÚVOD}

Lidstvo celá tisíciletí vzhlíželo k nebeským tělesům jako k něčemu velmi vzdálenému, nedosažitelnému a připisovalo jim zejména kulturní a náboženský význam. V literárních a uměleckých dílech byly představovány myšlenky lidské kolonizace nebeských těles, ale až do úspěšného uskutečnění mise Apollo 11 šlo spíše o sny a fantazie. Mise Apollo 11 si však kromě přistání člověka na jiném nebeském tělese připsala ještě jedno důležité prvenství. Zpátky na Zemi totiž přinesla první měsíční geologické vzorky. Dvacet dva kilogramů materiálu, včetně měsíčních kamenů a měsíč-

1 Text tohoto článku vychází z diplomové práce s názvem Právní režim přirodních zdrojů na nebeských tělesech, která byla obhájena 27. 1. 2021 na Právnické fakultě Univerzity Karlovy (Digitální repozitář Univerzity Karlovy [online]. Dostupné na: https://dspace.cuni.cz/handle/20.500.11956/124444). 
ního regolitu získaného z povrchu a také z hloubky až třinácti centimetrů pod povrchem Měsíce. ${ }^{2}$

V posledních letech lze sledovat proměnu ve vnímání nebeských těles lidstvem. Stále více lidí a společností upírá svůj zrak k planetám, měsícům, kometám a asteroidům, ve kterých už nevidí jen uměleckou inspiraci či podoby božstev, ale nově také potenciál ekonomického zisku. Podle investiční bankovní společnosti Goldman Sachs ${ }^{3}$ i podle astrofyzika Neila deGrasse Tysona ${ }^{4}$ budou prvními dolarovými „,bilionáŕi“ “ právě ti, kteří se začnou věnovat využivání a těžbě přírodních zdrojů v kosmickém prostoru a na nebeských tělesech.

10. záŕí 2020 vydal americký Národní úřad pro letectví a kosmonautiku (dále jen „NASA“) výzvu soukromým společnostem k předložení nabídek na sběr kosmických zdrojů, $\mathrm{k}$ nimž by práva následně byla za úplatu převedena na NASA. Podle tehdejš́ího ředitele NASA Jima Bridenstinea byla důvodem tohoto kroku snaha dokázat, že je taková aktivita možná a že je na čase, aby byl dán základ regulační jistotě při získávání kosmických zdrojů a obchodování s nimi. ${ }^{5}$ Tato výzva nebyla určena pouze soukromým společnostem sídlícím ve Spojených státech amerických, ale všem soukromým společnostem z celého světa, které jsou schopny získat mezi padesáti a pěti sty gramy měsíčního regolitu do roku 2024 a následně převést vlastnická práva $\mathrm{k}$ těmto zdrojům na NASA. 3. prosince 2020 pak NASA oznámila výběr čtyř společností, se kterými uzavřela smlouvu na získání a dopravu měsíčních prrírodních zdrojů a následné převedení práv k nim na NASA. ${ }^{6}$

O prŕrodní zdroje obecně je stále větší zájem, ale až v poslední době lze spatřovat technologický pokrok, který by v relativně blízké budoucnosti mohl umožnit také získávání a využívání těch přírodních zdrojů, které se nachází mimo planetu Zemi.

Tento článek se zabývá posouzením právního režimu přírodních zdrojů v kosmickém prostoru a na nebeských tělesech, a to z pohledu Smlouvy o zásadách činnosti států při výzkumu a využívání kosmického prostoru včetně Měsíce a jiných nebeských těles (dále jen „Kosmická smlouva“) i Dohody o činnosti států na Měsíci a jiných nebeských tělesech (dále jen „Dohoda o Měsíci“). Je zde posuzováno, zda je na základě těchto mezinárodních dokumentů možné si kosmické zdroje ${ }^{7}$ přivlastnit a využívat je.

2 Apollo 11 Mission. In: Lunar and Planetary Institute [online]. [cit. 2020-12-02]. Dostupné na: https:// www.lpi.usra.edu/lunar/missions/apollo/apollo_11/samples/.

3 WEHNER, M. Asteroid mining will produce the world's first trillionaire, according to Goldman Sachs. In: $B G R$ [online]. 23. 4. 2018 [cit. 2020-12-02]. Dostupné na: https://bgr.com/2018/04/23/asteroid-mining -trillionaire-goldman-sachs-report/.

4 KRAMER, K. Neil deGrasse Tyson Says Space Ventures Will Spawn First Trillionaire. In: NBC News [online]. 3. 5. 2015 [cit. 2020-12-02]. Dostupné na: https://www.nbcnews.com/science/space/neil-degrasse-tyson-says-space-ventures-will-spawn-first-trillionaire-n352271.

5 WALL, M. NASA wants to buy moon dirt from private companies. In: Space [online]. 10. 9. 2020 [cit. 2020-10-16]. Dostupné na: https://www.space.com/nasa-buy-moon-dirt-private-companies.html.

6 SCHIERHOLZ, S. - FINCH, J. NASA Selects Companies to Collect Lunar Resources for Artemis Demonstrations. In: National Aeronautics and Space Administration [online]. 3. 12. 2020 [cit. 2020-12-05]. Dostupné na: https://www.nasa.gov/press-release/nasa-selects-companies-to-collect-lunar-resources-for -artemis-demonstrations.

7 Kosmickými zdroji jsou př́rodní zdroje nacházející a vyskytující se v kosmickém prostoru a na nebeských tělesech. Jsou jimi jak nerostné suroviny, tak energie, záření a další nehmotné statky. Jejich společnou 


\section{PRÁVNÍ REŽIM PŘÍRODNÍCH ZDROJU゚ NA NEBESKÝCH TĚLESECH PODLE KOSMICKÉ SMLOUVY}

\subsection{LEGALITA PŘIVLASTNĚNÍ KOSMICKÝCH ZDROJŮ}

Vyřešení otázky existence určitých práv ke kosmickým zdrojům je zásadní pro jejich faktické získávání a využívání. Subjekty (at' už státy, mezinárodní organizace, nebo soukromé společnosti a osoby) potřebují určitou právní jistotu, která by chránila jejich investice $\mathrm{v}$ této oblasti. Podmínkou komerčního získávání kosmických zdrojů, které je motivováno ziskem z jejich následného využívání, je určitá forma práv ke zdrojům, které mají být využívány. ${ }^{8}$

V této kapitole bude analyzován obsah Kosmické smlouvy a na základě jeho výkladu bude argumentováno, že zásada zákazu přivlastnění se na př́rodní zdroje v kosmickém prostoru a na nebeských tělesech nevztahuje.

Na významu zásady zákazu přivlastnění, vyjádřené v Kosmické smlouvě, nepanuje $\mathrm{v}$ akademické sfére úplná shoda. Dle některých autorů lze tuto zásadu interpretovat tak, že nezakazuje přivlastnění kosmických zdrojů soukromými osobami, pokud to zároveň neznamená výkon suverenity ze strany státu. ${ }^{9}$ Podle jiných autorů zásada vyjadřuje i zákaz vytváření práv soukromého vlastnictví, protože přivlastnění soukromými osobami by fakticky vyprázdnilo její obsah, který spočívá $\mathrm{v}$ zachování kosmického prostoru a nebeských těles pro volný výzkum a využívání bez jakékoli diskriminace a ve prospěch celého lidstva. ${ }^{10}$

Článek 2 Kosmické smlouvy stanoví zásadu zákazu přivlastnění vyjádřením, že , kosmický prostor včetně Měsíce a jiných nebeských těles si jednotlivé státy nemohou přivlastnit prohlášením suverenity, uživánim, okupaci nebo jakýmkoli jiným zpưsobem ". ${ }^{11}$ Ustanovení výslovně zakazuje přivlastnění12 kosmického prostoru a nebeských těles, o přírodních zdrojích se nezmiňuje. Základním účelem tohoto ustanovení je zabránit územním konfliktům mezi státy v kosmickém prostoru a na nebeských tělesech,

vlastností je skutečnost, že se nacházejí v kosmu, tedy mimo planetu Zemi a její atmosféru a většina z nich je tedy vzhledem $\mathrm{k}$ současné technologické úrovni alespoň prozatím těžko dosažitelná.

8 HARN, N. Commercial Mining of Celestial Bodies: a Legal Roadmap. Georgetown Environmental Law Review [online]. 2015, Vol. 27, No. 4 [cit. 2020-11-19]. Dostupné na: https://gielr.files.wordpress.com /2015/12/harn.pdf.

9 Srov. LEE, R. J. Creating a Practical Legal Framework for the Commercial Exploitation of Mineral Resources in Outer Space. Dizertační práce. Perth: Murdoch University, 2009, s. 342-344; GOROVE, S. Interpreting Article II of the Outer Space Treaty. Fordham Law Review [online]. 1969, Vol. 37, No. 3 , s. 351-352 [cit. 2020-11-19]. Dostupné na: https://ir.lawnet.fordham.edu/cgi/viewcontent.cgi?article $=1966 \&$ context $=$ flr.

10 Srov. TENNEN, L. I. Outer Space: a Preserve for All Humankind. Houston Journal of International Law [online]. 1979, Vol. 2, No. 1, s. 151 [cit. 2020-11-14]. Dostupné na: https://heinonline.org/HOL/P?h=hein .journals/hujil2\&i=153; ZULLO, K. M. The Need to Clarify the Status of Property Rights in International Space Law. The Georgetown Law Journal [online]. 2002, Vol. 90, No. 7, s. 2420 [cit. 2020-11-14]. Dostupné na: https://heinonline.org/HOL/P?h=hein.journals/glj90\&i=2435.

11 Smlouva o zásadách činnosti států při výzkumu a využívání kosmického prostoru včetně Měsíce a jiných nebeských těles, Čl. 2.

12 Takové přivlastnění (appropriation) Blackův právnický slovník popisuje jako učinění věci předmětem vlastnictví, vykonávání panství nad věcí takovým způsobem a v takovém rozsahu, aby sloužil vlastnímu uživání. 
aby zůstaly volné pro výzkum a využívání všemi státy bez jakékoli diskriminace, jak požaduje článek 1 Kosmické smlouvy. Jestliže tedy zásada stanoví zákaz přivlastnění kosmického prostoru a nebeských těles za účelem, aby bylo umožněno jejich využívání, a takovým př́ipustným využiváním je získávání přírodních zdrojů, nemůže se zásada zákazu přivlastnění na tyto získané př́rodní zdroje vztahovat.

Vzhledem $\mathrm{k}$ tomu lze tedy konstatovat, že zákaz přivlastnění kosmického prostoru včetně Měsíce a jiných nebeských těles, vztahující se ke kosmickému prostoru jako celku a na nebeská tělesa jako taková, není použitelný na získané př́rodní zdroje v kosmickém prostoru a na nebeských tělesech. ${ }^{13}$

\subsection{LEGALITA VYUŽÍVÁNÍ KOSMICKÝCH ZDROJU゚}

Dále je třeba zodpovědět otázku, zda je získávání, těžba a zužitkování kosmických zdrojů př́pustným způsobem jejich využívání, ve smyslu ustanovení článku 1 Kosmické smlouvy. Kosmická smlouva neobsahuje definici využívání kosmického prostoru, nebeských těles či jejich zdrojů. V Kosmické smlouvě lze nalézt demonstrativní výčet různých činností, které jsou bud' zakázány, nebo které jsou specificky upraveny. Př́kladem těch zakázaných způsobů využívání kosmického prostoru včetně nebeských těles je zavádění a rozmistování jaderných zbraní. ${ }^{14}$ Upraveným způsobem využívání je např́íklad vypouštění a obstarávání vypouštění objektů do kosmického prostoru včetně nebeských těles ${ }^{15}$ nebo umistování stanic, zařízení, výstroje a kosmických plavidel na nebeských tělesech. ${ }^{16}$

Článek 1 Kosmické smlouvy stanoví, že kosmický prostor včetně nebeských těles je volný pro výzkum a využívání na základě rovnosti a podle mezinárodního práva. ${ }^{17}$ O využívání prírodních zdrojů v kosmickém prostoru a na nebeských tělesech ve smyslu jejich těžby, zužitkování a komercializace se nezmiňuje. O výzkumu a využívání kosmických zdrojů (využívání ve smyslu těžby a zužitkování) ${ }^{18}$ se nicméně hovoří již v Rezoluci Valného shromáždění Organizace spojených národů RES 1348 (XIII), kterou byl mimo jiné zřízen Výbor Organizace Spojených národů pro mírové využívání kosmického prostoru (dále jen „COPUOS“). S ohledem na demonstrativní výčet způsobů využívání kosmického prostoru včetně nebeských těles; na to, že Kosmická smlouva uvažovaný způsob využívání neupravuje; a na to, že zásada zákazu přivlastnění se na

13 MAN, P. DE. The Commercial Exploitation of Outer Space and Celestial Bodies - A Functional Solution to the Natural Resource Challenge. In: SUNDAHL, J. M. - GOPALAKRISHNAN, V. (eds.). New Perspectives on Space Law: Proceedings of the 53rd IISL Colloquium on The Law of Outer Space: Young Scholars Session [online]. Paris: The International Institute of Space Law, 2011, s. 58 [cit. 2020-11-14]. Dostupné na: https://iislweb.org/docs/NewPerspectivesonSpaceLaw.pdf.

14 Smlouva o zásadách činnosti států při výzkumu a využívání kosmického prostoru včetně Měsíce a jiných nebeských těles, Čl. 4.

15 Tamtéž, Čl. 7.

16 Tamtéž, Čl. 12.

17 Tamtéž, Čl. 1.

18 V originále použité slovo exploitation se do češtiny překládá jako využívání. Aby došlo k odlišení od stejně překládaného pojmu use, byl v tomto případě zvolen překlad, který lépe odpovídá významu anglického exploitation a zároveň jej odlišuje od pojmu use. 
kosmické zdroje nevztahuje, lze konstatovat, že těžení a zužitkování přírodních zdrojů je př́ípustným způsobem jejich využívání. ${ }^{19}$

Problematickým však zůstává vymezení požadavku, vyjádřeného v článku 1 Kosmické smlouvy, dle kterého má být výzkum a využivání kosmického prostoru a nebeských těles prováděn pro blaho ${ }^{20}$ všech zemí. Podle R. Leeho existují čtyři hlavní postoje $\mathrm{k}$ tomuto požadavku:

1) Komerční kosmické aktivity nejsou ze své podstaty ku prospěchu ani v zájmu všech států, byt' z nich může mít prospěch jeden či několik států, a proto jsou v rozporu s článkem 1 Kosmické smlouvy.

2) Komerční kosmické aktivity jsou př́nosem pro všechny státy, pokud je v souvislosti s výnosnou činností poskytována všem státům určitá forma veřejné služby. ${ }^{21}$

3) Komerční kosmické aktivity jsou v souladu s požadavkem př́nosu pro všechny státy, pokud jimi poskytované zboží nebo služby mohou být získány kterýmkoli subjektem bez jakékoli diskriminace.

4) Komerční kosmické aktivity splňují požadavek přínosu pro všechny státy, pokud povaha a druh činnosti nebrání žádnému jinému subjektu ve stejné činnosti. ${ }^{22}$

R. Lee dále tvrdí, že vzhledem $\mathrm{k}$ současné praxi států a obecnému přesvědčení je nepravděpodobné, že by se situace $\mathrm{v}$ budoucnu vyvíjela podle prvního nebo druhého stanoviska. První popsaný pohled na požadavek výzkumu a využívání kosmického prostoru a nebeských těles pro blaho všech zemí by komerční aktivity prováděné za tímto účelem úplně vyloučil. Druhý popsaný pohled by požadavek provádění aktivit pro blaho všech zemí vykládal jako uložení pozitivní povinnosti sdílení prospěchu z provádění těchto aktivit.

R. Lee se přiklání ke třetímu a čtvrtému popsanému postoji, $\mathrm{k}$ požadavku př́nosu pro všechny státy, ve kterých lze zároveň spatřovat podobnost s právním režimem využivání zdrojů mořského dna za hranicemi národní jurisdikce. V př́ípadě komerčních aktivit v oblasti př́rodních zdrojů na nebeských tělesech by tak mohl požadavek př́nosu pro všechny státy znamenat povinnost zpř́ístupnit ze zdrojů získaný prospěch všem státům bez jakékoli diskriminace, i když ne nutně za přiměřených cenových podmínek. ${ }^{23}$

Blaho či prospěch jsou velmi subjektivními pojmy. Jednak určitá činnost může být ve prospěch jedné země, ale v neprospěch jiné, a zároveň to, co je ve prospěch určitého státu dnes, nemusí být $\mathrm{v}$ jeho prospěch $\mathrm{v}$ budoucnosti. Aby určitá činnost byla ve prospěch všech států, musí být z logiky věci ve prospěch také toho státu či subjektu, který

19 MAN, c. d., s. 58-59.

20 V originále použité slovo benefit (v českém znění Kosmické smlouvy překládané jako blaho) se do češtiny překládá též jako užitek, prospěch, př́ínos. Je-li proto v této kapitole použit jeden z těchto alternativních překladů, myslí se tím vždy význam originálního pojmu benefit.

21 Př́ikladem podobné veřejné služby požadované mezinárodní smlouvou může být zajištování trvalého poskytování služeb globální námořní tísňové a bezpečnostní družicové komunikace na základě článku 3 Úmluvy o Mezinárodní družicové organizaci pro pohyblivé služby. Viz též International Mobile Satelite Organization. English Text of the IMSO Convention Amended as Adopted by the Twentieth Session of the IMSO Assembly Provisionally Applied from 6 October 2008 [online]. [cit. 2020-11-14]. Dostupné na: https://imso.org/wp-content/uploads/2019/08/E.IMSO-CONVENTION.pdf.

22 LEE, c. d., s. 324-325.

23 Tamtéž, s. 325-327. 
ji provádí. Aby byla tedy uskutečněna činnost, která je ve prospěch všech států, musí ji určitý stát či jiný subjekt vůbec provést a $\mathrm{k}$ tomu musí být určitým způsobem motivován. Lze se tedy domnívat, že požadavek provádění výzkumu a využívání kosmického prostoru včetně nebeských těles pro blaho a v zájmu všech zemí je spíše požadavkem nediskriminačního přístupu při sdílení prospěchu získaného z kosmických zdrojů komerčním či jiným způsobem než požadavkem obligatorního faktického sdílení prospěchu se všemi státy. ${ }^{24}$

\subsection{SHRNUTÍ}

Kosmický prostor a nebeská tělesa jsou volné pro výzkum a využívání všemi státy. Takovým využíváním může být mimo jiné získávání, zužitkování i zcizování kosmických zdrojů. Získané prírodní zdroje v kosmickém prostoru a na nebeských tělesech si lze přivlastnit za předpokladu, že tím není uplatňován nárok na kosmické zdroje in situ či nebeská tělesa, kosmický prostor a jejich části.

Využívání kosmických zdrojů, jako projev svobody využívání kosmického prostoru včetně nebeských těles, musí být prováděno v souladu s požadavkem př́nosu pro všechny státy, jeho provádění nesmí vylučovat z obdobných činností jiné státy či subjekty a v jeho rámci musí být ke všem státům přistupováno na základě rovnosti, bez jakékoli diskriminace a podle mezinárodního práva.

Takovéto činnosti mohou být prováděny státy, ale i jinými subjekty, vládními organizacemi, soukromými společnostmi i osobami. Za činnosti státní, ale i jiných subjektů, a za soulad těchto činností s mezinárodním právem nese mezinárodní odpovědnost smluvní stát, který danou činnost povolil a který nad ní vykonává trvalou kontrolu. Za tímto účelem by státy měly přijímat legislativu, která by kosmické činnosti jejich občanů upravovala. Při jejím formulování by se pak měly řídit doporučeními a zásadami, vyjádřenými v Building Blocks for the Development of an International Framework for the Governance of Space Resource Activities a v Zásadách dlouhodobé udržitelnosti v kosmickém prostoru, aby byly vnitřní předpisy států porovnatelné mezi sebou a v ideálním prrípadě také obsahově obdobné.

\section{PRÁVNÍ REŽIM PŘÍRODNÍCH ZDROJU゚ NA NEBESKÝCH TĚLESECH PODLE DOHODY O MĚSÍCI}

Dohodu o Měsíci ratifikovalo či k ní přistoupilo pouze osmnáct států, mezi kterými není ani jedna z kosmických velmocí. Právní režim př́rodních zdrojů na nebeských tělesech podle Dohody o Měsíci je zde zkoumán z důvodu, že jde o jednu z mála mezinárodních smluv v oblasti kosmického práva a první a zatím jedinou, která upravuje využívání přírodních zdrojů na nebeských tělesech. Proto i přes nízký počet smluvních států a skutečnost, že Dohoda o Měsíci je mnohými teoretiky i státy pova-

${ }^{24}$ Rovněž je vhodné poznamenat, že někteří autoři mají za to, že požadavek provádění aktivit pro blaho a v zájmu všech zemí je spíše vyjádřením morálního závazku než zákonné povinnosti. Srov. LEE, $c$. $d$., s. 316-317. 
žována za neúspěšný pokus o mezinárodněprávní úpravu postavení Měsíce a jiných nebeských těles a jejich př́rodních zdrojů, je zde argumentováno, že Dohoda o Měsíci není nezbytně odsouzena $\mathrm{k}$ tomu, aby skončila mezi mezinárodními smlouvami, které nenaplnily své ambice na univerzální príjetí.

\subsection{LEGALITA PŘIVLASTNĚNÍ KOSMICKÝCH ZDROJU゚}

Dohoda o Měsíci obsahuje ve druhém odstavci článku 11 zásadu zákazu přivlastnění Měsíce a jiných nebeských těles, ${ }^{25}$ jejíž formulace je obdobná, nicméně podrobnější oproti té, vyjádřené v Kosmické smlouvě. Článek 11 Dohody o Měsíci explicitně zakazuje přivlastnění povrchu, podzemí, jejich částí i př́rodních zdrojů in situ státy, mezinárodními mezivládními či nevládními organizacemi, národními organizacemi nebo nevládními subjekty a jakýmikoli fyzickými osobami. Dále specifikuje, že umístěním personálu, kosmických plavidel, výstroje, vybavení, stanic a zařízení na povrchu či pod povrchem nebeských těles nevznikne subjektu vlastnické právo k danému nebeskému tělesu ani jeho části. ${ }^{26}$

Z obsahu takto vyjádřené zásady zákazu přivlastnění nebeských těles zjevně vyplývá, že není jejím účelem zamezit získávání a využivání přírodních zdrojů z Měsíce a jiných nebeských těles, ale zabránit územním konfliktům; naplnit obsah zásady common heritage of mankind, která Měsíc, nebeská tělesa a jejich př́rodní zdroje označuje za společné dědictví lidstva; a umožnit jejich mírové využívání. Vzhledem k doslovnému zákazu přivlastnění př́rodních zdrojů in situ a $\mathrm{k}$ výčtu činností, které nevedou ke vzniku vlastnického práva $\mathrm{k}$ nebeskému tělesu či jeho části, lze a contrario dovodit, že získané prrírodní zdroje oddělené od původního nebeského tělesa jsou způsobilé přivlastnění. Ze zákazu přivlastnění př́rodních zdrojů in situ vyplývá, že uplatňování nároku na př́rodní zdroje je legitimní, pouze pokud je spojeno s jejich využíváním. V opačném př́ípadě by totiž šlo o faktické uplatňování suverenity nad určitou částí nebeského tělesa. Skutečnost, že jsou přírodní zdroje využívány, je činí způsobilými k přivlastnění. ${ }^{27}$

\subsection{LEGALITA VYUŽÍVÁNÍ PŘíRODNÍCH ZDROJU゚}

Dohoda o Měsíci je oproti Kosmické smlouvě v této otázce jednoznačnější. V preambuli Dohody o Měsíci je brán na vědomí prospěch, který může vznikat z využívání (využívání ve smyslu těžby a zužitkování) zdrojů na nebeských tělesech. V ustanovení, ve kterém se smluvní státy zavazují k vytvoření mezinárodního režimu, je vyjádřen smysl tohoto režimu, spočívající ve správě využívání (ve smyslu těžby a zužitkování) prŕírodních zdrojů na nebeských tělesech. ${ }^{28}$

\footnotetext{
25 Článek 11 Dohody o Měsíci hovoří pouze o Měsíci, ale na základě prvního odstavce článku 1 Dohody o Měsíci se ustanovení této Dohody vztahující se k Měsíci použijí jako lex generalis rovněž na jiná nebeská tělesa uvnitř Sluneční soustavy (s výjimkou Země), pokud tato nemají speciální úpravu.

${ }^{26}$ Dohoda o činnosti států na Měsíci a jiných nebeských tělesech, Čl. 11.

27 MAN, c. d., s. 56-57.

28 Dohoda o činnosti států na Měsíci a jiných nebeských tělesech, Čl. 11.
} 
Dohoda o Měsíci stanoví, že smluvní státy mohou vykonávat své aktivity v rámci výzkumu a využívání nebeských těles kdekoli na jejich povrchu a pod ním. K tomuto uvádí demonstrativní výčet takových způsobů využívání. Patří mezi ně možnost přistávat s kosmickými objekty na nebeských tělesech, umist'ovat na povrchu a v podzemí nebeských těles personál, kosmická plavidla, výstroj, zařízení a stanice. ${ }^{29}$

Dohoda o Měsíci rovněž uvádí způsoby využívání nebeských těles, které jsou zakázány. Mezi ty patří umist'ování jaderných zbraní a jakýchkoli jiných zbraní hromadného ničení na nebeská tělesa nebo jejich oběžné dráhy. ${ }^{30}$

Vzhledem k demonstrativnímu výčtu způsobů využívání nebeských těles a s ohledem na výslovné zmínění využívání ve smyslu těžby a zužitkování přírodních zdrojů a skutečnost, že takový způsob využívání nebeských těles není Dohodou o Měsíci zakázán, lze konstatovat, že jde o př́pustný způsob využívání Měsíce a jiných nebeských těles.

Právní režim př́rodních zdrojů na nebeských tělesech podle Dohody o Měsíci je oproti úpravě Kosmické smlouvy detailnější a obsahuje více povinností, které se k využivání vážou. Mezi tyto patří povinnost států informovat generálního tajemníka Organizace spojených národů, veřejnost a mezinárodní vědeckou obec ohledně jejich aktivit v oblasti využívání nebeských těles a ohledně jimi objevených jevů, které by mohly znamenat nebezpečí pro lidský život či zdraví nebo být známkou mimozemského života. ${ }^{31}$ Povinnost přijímat opatření $\mathrm{k}$ zabránění narušení stávající rovnováhy prostředí nebeského tělesa a informovat o přijímaných opatřeních generálního tajemníka Organizace spojených národů. ${ }^{32}$ Dále povinnost provádět aktivity v oblasti př́rodních zdrojů na nebeských tělesech způsobem slučitelným s účelem předpokládaného mezinárodního rámce, jímž je jejich řádný a bezpečný rozvoj, rozumná správa a rozšiřování př́ležitostí při využívání přírodních zdrojů, a spravedlivé sdílení prospěchu získaného z přírodních zdrojů se zvláštním ohledem na rozvojové státy a státy, které prrímo či nepř́mo přispěly k průzkumu nebeských těles. ${ }^{33}$

Dohoda o Měsíci, podobně jako Kosmická smlouva, zakládá mezinárodní odpovědnost smluvních států za provádění národních aktivit na nebeských tělesech v souladu s Dohodou o Měsíci a s mezinárodním právem. Tuto odpovědnost smluvní státy nesou za aktivity vládních i nevládních subjektů a za zajištění provádění aktivit v souladu s ustanoveními Dohody o Měsíci. Spolu s tím Dohoda o Měsíci ukládá smluvním státům povinnost zabezpečit provádění národních aktivit pouze na základě povolení a trvalé kontroly ze strany př́slušného smluvního státu. ${ }^{34}$

Dohoda o Měsíci prohlašuje nebeská tělesa a jejich prrírodní zdroje za společné dědictví lidstva a zároveň stanoví, že význam tohoto pojmu je vyjádřen $\mathrm{v}$ ustanoveních Dohody o Měsíci a zejména $\mathrm{v}$ pátém odstavci článku 11. V tomto odstavci se smluvní státy Dohody o Měsíci zavazují vytvořit mezinárodní režim, včetně vhodných postupů,

\footnotetext{
9 Tamtéž, Čl. 8.

30 Tamtéž, Čl. 3.

1 Tamtéž, Čl. 5.

2 Tamtéž, Čl. 7.

Tamtéž, Čl. 11.

4 Tamtéž, Čl. 14.
} 
pro správu využívání přírodních zdrojů na nebeských tělesech, až se bude takové využívání přírodních zdrojů zdát proveditelné. ${ }^{35}$

Někteří autoři tvrdí, že toto ustanovení znamená zákaz využívání př́írodních zdrojů na nebeských tělesech do té doby, než bude zamýšlený mezinárodní režim vytvořen. ${ }^{36}$ Tento názor lze však rozporovat na základě analýzy doslovných záznamů COPUOS pořizovaných při přípravě návrhu Dohody o Měsíci. Zástupce Spojených států amerických při závěrečné řeči prohlásil, že navrhované znění článku 11 Dohody o Měsíci, které je součástí kompromisů učiněných mnoha delegacemi, nezakládá dočasný zákaz využívání přírodních zdrojů na nebeských tělesech a ani jej nepodmiňuje vytvořením mezinárodního režimu. Díky tomu bude možné dokázat proveditelnost a praktičnost těžby přírodních zdrojů, na základě čehož bude následně možné diskutovat vytvoření požadovaného mezinárodního režimu. ${ }^{37}$

Třemi teoretickými podmínkami zásady common heritage of mankind jsou zákaz přivlastnění takového mezinárodního prostoru spočivající v zákazu výkonu státní suverenity; právo států podílet se na výzkumu a využívání mezinárodního prostoru; a spravedlivé rozdělování prospěchu získaného z prúrodních zdrojů mezinárodního prostoru. ${ }^{38}$ Aby mohlo docházet ke spravedlivému rozdělování prospěchu získaného z př́rodních zdrojů, které je znakem společného dědictví lidstva, musí být př́rodní zdroje využívány a z tohoto využívání musí plynout nějaký prospěch. Prohlášení mezinárodního prostoru za společné dědictví lidstva tedy nemůže vylučovat jeho využívání, protože tím by docházelo k popření samotné zásady common heritage of mankind.

Z dikce pátého odstavce článku 11 Dohody o Měsíci; ze skutečnosti, že dočasný zákaz těžby a zužitkování př́rodních zdrojů na nebeských tělesech byl v př́ípravě Dohody o Měsíci diskutován (byt' v jejím platném znění zjevně chybí); a z teoretického vymezení mezinárodního prostoru, který je společným dědictvím lidstva, lze vyvodit, že vytvoření mezinárodního režimu není podmínkou pro využívání př́rodních zdrojů na nebeských tělesech ve smyslu jejich těžby a zužitkování a k takovému využívání tedy může docházet i před vznikem tohoto mezinárodního režimu.

\subsection{SHRNUTÍ}

Dohoda o Měsíci prohlašuje nebeská tělesa a jejich př́rodní zdroje in situ za společné dědictví lidstva. Tato zásada zákazu přivlastnění však neznamená zákaz získávání a využívání přírodních zdrojů. Dohoda o Měsíci výslovně zakazuje přivlastnění povrchu a podzemí nebeských těles, jejich částí a př́rodních zdrojů in situ; legálně získané prírodní zdroje - tedy ty látky, materiály a nehmotné jevy, které jsou získány

35 Tamtéž, Čl. 11.

36 Srov. LISTNER, M. The Moon Treaty: failed international law or waiting in the shadows? In: The Space Review [online]. 24. 10. 2011 [cit. 2020-11-27]. Dostupné na: https://www.thespacereview.com /article/1954/1.

37 Commitee on the Peaceful Uses of Outer Space. Verbatim Record of the Two Hundred and Third Meeting [online]. 16. 7. 1979 [cit. 2020-11-27]. Dostupné na: https:/www.unoosa.org/pdf/transcripts/copuos /AC105_PV203E.pdf.

38 DAVID, V. - SLADKÝ, P. - ZBOŘIL, F. Mezinárodni právo veřejné s kazuistikou. Praha: Leges, 2008, s. 274 . 
oddělením z povrchu, podzemí a přírodních zdrojů in situ - jsou způsobilé přivlastnění za předpokladu, že přivlastnění prrírodních zdrojů je spojeno s jejich využíváním.

V článku 11 je smluvním státům dáno právo využívat nebeská tělesa na základě rovnosti a bez jakékoli diskriminace. Využívání prrírodních zdrojů ve smyslu jejich získávání, těžby a zužitkování je přípustným zpơsobem využívání nebeských těles podle Dohody o Měsíci. K naplnění zásady common heritage of mankind a za účelem správy využívání prírodních zdrojů se pak smluvní státy zavazují vytvořit mezinárodní režim, který však není podmínkou pro využívání přírodních zdrojů. Dalo by se tedy říci, že existující právní režim př́rodních zdrojů na nebeských tělesech podle Dohody o Měsíci je provizorním režimem, platným do doby, než bude vytvořen zamýšlený mezinárodní režim.

Za soulad s Dohodou o Měsíci a s mezinárodním právem při provádění takových činností vládními či nevládními subjekty nese mezinárodní odpovědnost smluvní stát, který k provádění dané činnosti udělil povolení a který nad ní uskutečňuje trvalou kontrolu. $\mathrm{K}$ tomuto účelu a také $\mathrm{k}$ naplnění zamýšleného mezinárodního režimu by státy měly přjímat vnitrostátní předpisy, upravující kosmické aktivity svých občanů. Při jejich vytváření by se měly nechat vést doporučeními a zásadami vyjádřenými v Building Blocks for the Development of an International Framework for the Governance of Space Resource Activities a v Zásadách dlouhodobé udržitelnosti v kosmickém prostoru, za účelem harmonizace národních legislativ a jejich vzájemného uznávání.

Přestože k Dohodě o Měsíci přistoupilo jen osmnáct států, domnívá se autor, že jde o mezinárodní dokument s potenciálem nabytí většího uznání v budoucnu. Na základě výkladu Dohody o Měsíci a srovnání jejího obsahu s Kosmickou smlouvu je argumentováno, že zásada zákazu přivlastnění nebeských těles, stanovená v Dohodě o Měsíci, se na přírodní zdroje nevztahuje, jestliže jsou získávány za účelem jejich využívání. Tímto využíváním může být z povahy věci jejich získávání i následné zužitkování. V tomto směru je tedy úprava Dohody o Měsíci podobná úpravě vyjádřené v Kosmické smlouvě. Podstatný rozdíl mezi nimi spočívá v zásadě common heritage of mankind, vyjádřené v Dohodě o Měsíci. Význam této zásady však není zcela jasný. Někteří autoři ji vykládají v tom smyslu, že zakazuje využívání př́irodních zdrojů na nebeských tělesech až do doby vytvoření mezinárodního režimu, který Dohoda o Měsíci předpokládá. Autor této práce předkládá argumenty proti tomuto názoru a tvrdí, že př́rodní zdroje na nebeských tělesech lze využívat i před vytvořením mezinárodního režimu. Na požadavek sdílení prospěchu získaného z př́rodních zdrojů lze opět nahlížet prostřednictvím zásad vyjádřených v Building Blocks for the Development of an International Framework for the Governance of Space Resource Activities s tím, že by nemělo být vyžadováno př́mé sdílení finančního prospěchu, ale spíše nediskriminační př́istup a spolupráce s ostatními státy, se zvláštním ohledem na rozvojové státy. 


\section{BUILDING BLOCKS FOR THE DEVELOPMENT OF AN INTERNATIONAL FRAMEWORK FOR THE GOVERNANCE OF SPACE RESOURCE ACTIVITIES}

V roce 2016 byla vytvořena Haagská mezinárodní pracovní skupina pro správu kosmických zdrojů (dále jen „Haagská pracovní skupina“), ${ }^{39}$ které bylo dáno za cíl posuzovat potřebu regulační struktury pro činnosti v oblasti kosmických zdrojů a následně připravit dokument představující základní použitelné prvky této struktury. V př́padě vzniku takové potřeby měla Haagská pracovní skupina podporovat a vést státy k jednání o mezinárodní dohodě nebo právně nezávazném dokumentu. ${ }^{40}$ Vzhledem k tomu, že dochází $\mathrm{k}$ vývoji činností, jejichž předmětem je využívání kosmických zdrojů, a s ohledem na neexistenci jasného rámce, který by tyto činnosti ř́dil, vyvstává zde potřeba přezkumu předkládaných koncepcí, aby byl zajištěn soulad s mezinárodními smlouvami v oblasti kosmických zdrojů. Takové koncepce musí umožňovat, podporovat a koordinovat využívání kosmických zdrojů a musí být přijatelné pro země s kosmickým programem i pro ostatní zúčastněné státy. ${ }^{41} \mathrm{Za}$ účelem reagovat na tyto požadavky a v souladu se svým vytyčeným cílem vydala v listopadu 2019 Haagská pracovní skupina dokument Building Blocks for the Development of an International Framework for the Governance of Space Resource Activities ${ }^{42}$ (Základní zásady pro rozvoj mezinárodního rámce pro ř́zení aktivit $\mathrm{v}$ oblasti kosmických zdrojů; dále jen „Building Blocks“). Building Blocks představují ve dvaceti bodech základní témata, která by měla být východisky pro mezinárodní diskuzi o př́padném vývoji mezinárodního rámce řídícího aktivity zaměřené na využívání kosmických zdrojů. Vypracováním tohoto dokumentu Haagská pracovní skupina zamýšlela přispět k národním, regionálním i světovým snahám o správu aktivit v oblasti kosmických zdrojů.

Building Blocks konstatují, že mezinárodní rámec by měl vytvořit prostředí umožňující provádění aktivit týkajících se kosmických zdrojů, ve kterém bude brán zřetel na zájmy a prospěch všech států a celého lidstva. Tento mezinárodní rámec by se měl zaměřit na státy i mezinárodní organizace a mohl by rovněž obsahovat regulaci jednání států, mezinárodních organizací i nevládních subjektů. Mezinárodní rámec by měl být koncipován tak, aby byl v souladu s principem přizpůsobivé správy, a to tím způsobem, že by postupně upravoval aktivity, které by se stávaly možnými, a tím přispíval

39 Haagská pracovní skupina je tvořena členy a pozorovateli a je pořádána konsorciem organizací ze všech kontinentů, jehož hlavním společníkem je Institut leteckého a kosmického práva Univerzity v Leidenu. Česká republika je mezi členy zastoupena delegátem Ministerstva dopravy a mezi pozorovateli zástupcem Univerzity Karlovy.

40 Committee on the Peaceful Uses of Outer Space, Legal Subcommittee. The Hague Space Resources Governance Working Group [online]. 2016 [cit. 2020-07-08]. Dostupné na: https://www.unoosa.org/res/oosadoc/data /documents/2016/aac_105c_22016crp/aac_105c_22016crp_17_0_html/AC105_C2_2016_CRP17E.pdf.

${ }^{41}$ International Institute of Air and Space Law. The Hague International Space Resources Governance Working Group. In: Leiden University [online]. [cit. 2020-07-08]. Dostupné na: https://www.universiteitleiden.nl/en/law /institute-of-public-law/institute-of-air-space-law/the-hague-space-resources-governance-working-group.

42 The Hague International Space Resources Governance Working Group. Building Blocks for the Development of an International Framework on Space Resource Activities [online]. 2019 [cit. 2020-07-10]. Dostupné na: https://www.universiteitleiden.nl/binaries/content/assets/rechtsgeleerdheid/instituut-voor-publiekrecht/lucht --en-ruimterecht/space-resources/final-bb.pdf. 
k udržitelnému vývoji aktivit a $\mathrm{k}$ udržitelnému, účinnému a bezpečnému využívání kosmických zdrojů, a aby poskytoval právní jistotu a předvídatelnost pro subjekty takové aktivity provádějící. Mezinárodní rámec by rovněž měl ustanovit využívání kosmických zdrojů pouze pro mírové účely a ve prospěch a v zájmu všech zemí a celého lidstva, bez ohledu na úroveň jejich hospodářského nebo vědeckého vývoje. Dále by měl zajistit mezinárodní odpovědnost států za aktivity týkající se kosmických zdrojů prováděné vládními i nevládními subjekty a že budou takové aktivity prováděny v souladu s tímto mezinárodním rámcem. Aktivity prováděné nevládními subjekty mají být podmíněny předchozím povolením a soustavnou kontrolou př́slušného státu. ${ }^{43}$

\subsection{PŘEDNOSTNÍ PRÁVO}

Vzhledem k tomu, že mezinárodní právo neumožňuje státům přivlastnit si kosmický prostor a nebeská tělesa prohlášením suverenity, užíváním, okupací nebo jakýmkoli jiným způsobem, Building Blocks doporučují, aby mezinárodní rámec umožňoval nabývání přednostních práv subjekty k vyhledání a získání kosmických zdrojü, a to na maximální určenou dobu a na maximální určené ploše, na základě registrace subjektů v mezinárodním registru. Mezinárodní rámec by měl rovněž zajistit mezinárodní uznání takových práv. Nabytí, doba a místo výkonu přednostního práva by měly být určeny na základě zvláštních okolností navrhované aktivity týkající se kosmických zdrojů. ${ }^{44}$ Přednostní práva by měla být subjekty registrována a rovněž by jimi měly být dopředu oznámeny zamýšlené aktivity a s nimi spojená bezpečnostní opatření. Subjekty by také měly oznámit ukončení takových aktivit, společně s prohlášením o stavu oblasti, ve které byly aktivity prováděny, a o přítomnosti jakýchkoli kosmických objektů či produktů nebo jejich částí. ${ }^{45}$ Systém přednostních práv je důležitý pro ochranu úsilí a investic subjektů při vyhledávání kosmických zdrojů a uskutečňování souvisejících aktivit a pro koordinaci př́stupu ke kosmickým zdrojům. ${ }^{46}$ Při posuzování legálnosti takového systému přednostních práv lze odkázat na článek 1 Kosmické smlouvy, článek 11 Dohody o Měsíci a rezoluci RES 1721 (XVI) Valného shromáždění Organizace spojených národů, které souhlasně stanoví, že kosmický prostor i nebeská tělesa jsou volné pro výzkum a využívání všemi státy v souladu s mezinárodním právem.

Mezinárodní rámec by měl také ustanovit vznik a zajištování veřejně př́stupného mezinárodního registru pro registraci přednostních práv subjektů k vyhledání a získání kosmických zdrojů. Rovněž by měl dát vzniknout mezinárodní databázi, ve které by byla zveřejňována oznámení subjektů o plánovaných aktivitách v oblasti kosmických zdrojů, včetně př́slušných bezpečnostních opatření, a oznámení o ukončení takových aktivit. Monitorování a kontrola dodržování mezinárodního rámce, stejně jako spravo-

43 Tamtéž, body 4-5.

44 Tamtéž, bod 7.

45 Tamtéž, bod 14, písmeno f).

46 BITTENCOURT NETO, O. DE O. - HOFMANN, M. - MASSON-ZWAAN, T. - STEFOUDI, D. (eds.). Building Blocks for the Development of an International Framework for the Governance of Space Resource Activities: a Commentary [online]. The Netherlands: Eleven International Publishing, 2020, s. 46 [cit. 2020-07-10]. Dostupné na: https://boeken.rechtsgebieden.boomportaal.nl/publicaties/9789462361218\#57. 
vání mezinárodního registru a mezinárodní databáze, by mělo příslušet mezinárodnímu orgánu, jehož vznik či ustanovení by měl mezinárodní rámec rovněž zajistit. ${ }^{47}$

\subsection{PRÁVO KE ZDROJƯM}

Mezinárodní rámec by podle Building Blocks měl zabezpečit legální možnost nabytí práv ke kosmickým zdrojům prostřednictvím vnitrostátní legislativy, dvoustranných či vícestranných mezinárodních dohod. Takové právo by umožňovalo získávat z kosmických zdrojů suroviny a látky a z těch zase další produkty. ${ }^{48}$ Aby byla zajištěna právní jistota subjektů a jejich ochota investovat do aktivit v oblasti kosmických zdrojů, mělo by nabývání těchto práv být na základě mezinárodního rámce státy vzájemně uznáváno. Haagská pracovní skupina původně uvažovala, zda by práva ke zdrojům měla být evidována $\mathrm{v}$ mezinárodním registru, nebo recipročně akceptována na základě vzájemného uznávání. Nakonec se rozhodla pro druhou z variant jako pro jednodušší a efektivnější nástroj spolupráce. Rovněž zaměnila původní prohlášení, podporující zákonnost plného využití nebeského tělesa, za odkaz na zásadu zákazu přivlastnění kosmického prostoru včetně nebeských těles, vyjádřenou v článku 2 Kosmické smlouvy. ${ }^{49}$

\subsection{SDÍLENÍ PROSPĚCHU Z VYUŽÍVÁNÍ KOSMICKÝCH ZDROJU゚}

Vzhledem k tomu, že výzkum a využívání kosmického prostoru by měly být prováděny ku prospěchu a v zájmu všech států a celého lidstva, měl by podle Building Blocks mezinárodní rámec zaručit, že státy a mezinárodní organizace, odpovědné za aktivity v oblasti kosmických zdrojů, zajistí sdílení prospěchu z nich prostřednictvím podpory účasti všech států na aktivitách týkajících se kosmických zdrojů, zejména států rozvojových. Mezinárodní rámec by neměl vyžadovat povinné sdílení finančních výhod. Subjekty provádějící tyto aktivity by však měly být ke sdílení prospěchu povzbuzovány. ${ }^{50}$ Státy a mezinárodní organizace by při provádění aktivit v oblasti kosmických zdrojů rovněž měly brát ohled na příslušné zájmy všech států a celého lidstva. ${ }^{51}$

Building Blocks rovněž předpokládají vznik nástroje pro sledování implementace mezinárodního rámce, např́klad na základě oznámení států a mezinárodních organizací. Tento nástroj by měl také sloužit ke kontrole a dalšímu vývoji mezinárodního rámce v souladu s principem přizpůsobivé správy. ${ }^{52}$ Bod 20 nepředkládá návrh na konkrétní podobu takového nástroje, pouze zdůrazňuje jeho důležitost pro uskutečňování kosmických aktivit. ${ }^{53}$

\footnotetext{
47 The Hague International Space Resources Governance Working Group, c. d., bod 18.

48 Tamtéž, bod 8.

49 BITTENCOURT, c. d., s. 53-54.

50 The Hague International Space Resources Governance Working Group, c. d., bod 13.

51 Tamtéž, bod 9 .

52 Tamtéž, bod 20.

53 BITTENCOURT, c. d., s. 104.
} 
Podle Bodu 11 by měly státy a mezinárodní organizace předem přezkoumat každé rozhodnutí směřující $\mathrm{k}$ aktivitám $\mathrm{v}$ oblasti kosmických zdrojů, čímž má být předcházeno škodlivým dopadům těchto aktivit. Náležitý postup takové kontroly by měl být ustanoven mezinárodním rámcem, aby bylo zaručeno, že tyto aktivity budou prováděny bezpečně. Požadavek předcházejících kontrol je vázán na článek 6 Kosmické smlouvy, podle kterého jsou státy odpovědné za národní aktivity prováděné v kosmickém prostoru, at již jsou uskutečňovány vládními organizacemi, nebo nevládními institucemi. ${ }^{54}$

\title{
ZÁVĚR
}

Přestože autor v tomto článku předkládá argumenty svědčící o legalitě získávání a využívání přírodních zdrojů na nebeských tělesech, je toho názoru, že by měl pokračovat mezinárodní dialog a mělo by být usilováno o shodu $\mathrm{v}$ př́stupu $\mathrm{k}$ těmto aktivitám. Kosmické zdroje by neměly být využivány na základě zásady přednosti prvního (first come, first served). Skutečnost, že Kosmická smlouva (i Dohoda o Měsíci) tyto aktivity nezakazuje, neznamená, že by měly být prováděny bez předchozího dosažení mezinárodního konsenzu. Současný stav životního prostředí a zásob nerostného bohatství planety Země může sloužit jako modelový př́klad, kterému by se lidstvo mělo na dalších nebeských tělesech snažit vyhnout.

Jak je z tohoto textu nejspíš zjevné, jeho autor je příznivcem Dohody o Měsíci a jí předpokládaného mezinárodního režimu, který by aktivity v oblasti př́rodních zdrojů na nebeských tělesech řídil. Autor se rovněž domnívá, že by bylo vhodné, kdyby se státy při vytváření tohoto mezinárodního režimu řídily doporučeními vyjádřenými v Building Blocks. Také by se mohly inspirovat režimem mořského dna za hranicemi národní jurisdikce. Postupováním obdobným způsobem jako v př́ípadě režimu mořského dna ${ }^{55}$ by bylo také možné pozvednout význam Dohody o Měsíci. Dohoda o Měsíci je zatím jediná mezinárodní smlouva, která se určitým způsobem snaží o zpřístupnění, ale také ochranu přírodních zdrojů nebeských těles. Zároveň usiluje o to, aby nebeská tělesa a jejich př́rodní zdroje nebyly předmětem konfliktů mezi jednotlivými státy, ale aby v rámci mezinárodní spolupráce sloužily všemu lidstvu jako celku.

\author{
Mgr. Šimon Pepř́ík \\ Ministerstvo spravedlnosti \\ simon.peprik@gmail.com
}

\footnotetext{
54 BITTENCOURT, c. d., s. 65-68.

$55 \mathrm{~V}$ př́padě Úmluvy OSN o mořském právu byl problém, který spočíval v neochotě států tuto Úmluvu ratifikovat, řešen prrijetím Dohody o provádění UNCLOS, která Úmluvu OSN o mořském právu upravila tak, aby byla přijatelnější pro vyspělé státy, a tedy celkově otevřenější pro více států. To splnilo svůj účel, vzhledem k tomu, že po přijetí Dohody o provádění UNCLOS 28. července 1994 přistoupily do současnosti k Úmluvě OSN o mořském právu další sto čtyři státy a také Evropská unie jako celek.
} 